DOI: 10.34015/2523-4552.2020.3.05

УдК 343.2

Матвєєва Л. Г.,

доктор юридичних наук, доцент, завідувач кафедри теорії та філософії права Одеського державного університету внутрішніх справ e-mail: liliya.matveeva@i.ua ORCID: 0000-0002-8402-5584

\title{
МІЖНАРОДНІ ТА ЄВРОПЕЙСЬКІ СТАНДАРТИ ЗАХИСТУ ПРАВ ВРАЗЛИВИХ ГРУП НАСЕЛЕННЯ
}

У статті розглянуто та проаналізовано проблеми правового захисту вразливих груп населення в контексті формування активної правозахисної політики держави, спрямованої на підвищення спроможності соціально вразливих груп та зниження ризиків зростання соціальної напруги у суспільстві. Презентовано результати аналізу європейського досвіду протидії нетерпимості та дискримінації.

Ключові слова: права людини; вразливі групи населення; дискримінація; злочини на грунті ненависті; практика ЕСПЛ.

В статье рассмотрены и проанализированы проблемы правовой защиты уязвимых групп населения в контексте формирования активной правозащитной политики государства, направленной на повышение способности социально уязвимых групп и снижения рисков роста социальной напряженности в обществе. Представлены результаты анализа европейского опыта противодействия нетерпимости и дискриминации.

Ключевые слова: права человека; уязвимые группы населения; дискриминация; преступления на почве ненависти; практика ЕСПЧ.

Постановка проблеми. У сучасних кризових умовах, населення України гостро відчуває нестабільність - у сім'ях, особистій безпеці, у соціальному оточенні, а також у глобальній політиці. Аналіз наукових та практичних досліджень у сфері прав людини в Україні, звітів національних, регіональних та міжнародних правозахисних організацій, доповідей Уповноваженого Верховної Ради України з прав людини, дає підстави говорити, що поряд 3 позитивними результатами реформування правової системи України, си- стемними залишаються порушення прав та свобод людини. Особливе місце в переліку таких порушень займають вразливі групи населення, які нездатні ефективно протидіяти неправомірним діям або захищати та відновлювати свої права у разі їх порушення. Актуальність проблеми підсилюється тим, що дискримінація, як прояв порушення прав представників окремих груп (за ознакою віку, здоров'я, соціального статусу, національності та інше) спричиняє глобальні негативні наслідки для суспільства та держави. 
Під вразливістю розуміємо такий стан, перебуваючи в якому особа позбавлена або обмежена у здатності чинити опір насильницьким чи іншим незаконним діям внаслідок фізичних чи психічних властивостей або інших обставин, зумовлених відповідними ознаками. Тою чи іншою мірою всі люди $\epsilon$ соціально вразливими перед природними катаклізмами або техногенними катастрофами. Вразливість населення підвищується у періоди політичної нестабільності, економічного спаду та правової невизначеності. Традиційно до вразливих груп населення відносять: людей похилого віку, хворих, жінок, дітей, представників різного роду меншин, а також осіб, що тимчасово потребують захисту.

На сучасному етапі суспільної еволюції, дуже важливо піднімати питання про правий захист вразливих груп населення та виносити обговорення проблеми як у середовищі науковців так і на рівні органів державної влади, громадських організацій. Метою таких обговорень $\epsilon$ виявлення масштабів та причин існуючих проблем, визначення правового механізму захисту вразливих груп населення.

Аналіз останніх досліджень та публікацій. Вразливість не $\epsilon$ чітко визначеним поняттям. Цим терміном користуються соціологи, демографи, психологи, економісти, екологи, медики, правники в контексті особливостей діяльності у певних сферах суспільного життя. Різним аспектам системи правового захисту вразливих груп населення в Україні присвячено праці провідних українських вчених, серед них: Д. Бойчук, Д. Вовк, В. Галан, Г. Журавльова, А. Кравчук, О. Радчук, та інші $[3 ; 4 ; 6 ; 10 ; 22]$. Предметом таких досліджень виступає проблема формування правової політики, аналіз причин низької ефективності правового захисту, розробка концептуальних засад організації, пошук нових та удосконалення чинних механізмів реалізації захисту вразливих груп населення. Проте у наукових дослідженнях недостатньо уваги приділяється оцінюванню та розробці нових напрямів правової підтримки. Особливої уваги потребують питання удосконалення методичних підходів до оцінювання правових програм і всієї системи правової підтримки в Україні, а також інтерпретації рішень Європейського Суду та використання їх при прийнятті правових рішень. Проблематика підсилюється тим, що значна поширеність порушень прав представників окремих груп, дискримінація їх за різними ознаками спричиняє глобальні негативні (правові, політичні, соціальні, економічні, демографічні) наслідки для суспільства в цілому. Так порушуються принципи верховенства права, законності, а отже і нівелюються ознаки правової держави.

Постановка завдання. Метою статті $\epsilon$ визначення ключових напрямів формування активної правової політики, спрямованої на підвищення спроможності соціально вразливих груп та зниження ризиків вразливості у суспільстві. Аналіз європейського досвіду протидії нетерпимості і дискримінації та вироблення пропозицій щодо вдосконалення вітчизняного законодавства.

Виклад основного матеріалу. Проблема подолання дискримінації $\epsilon$ актуальною для більшості сучасних держав, і України зокрема. Реалізація 
такого завдання пов'язана з забезпеченням основних прав і свобод людини, закріплених у міжнародних, регіональних та вітчизняних нормативно-правових актах.

Визнаючи природний характер прав людини, у ст. 1 Загальної декларації прав людини проголошено, що «всі люди народжуються вільними і рівними у своїй гідності і правах». А в ст. 2 констатується - «кожна людина повинна мати всі права і всі свободи, проголошені Декларацією, незалежно від раси, кольору шкіри, статі, мови, релігії, політичних або інших переконань, національного чи соціального походження, майнового, станового або іншого становища» [7]. Конституції багатьох країн світу містять посилання на цей міжнародний документ та включають низку його положень. На Декларацію часто посилаються при тлумаченні національного законодавства з прав людини, а також у судовій практиці.

Міжнародний пакт про громадянські і політичні права також встановлює загальну заборону дискримінації за будь-якою ознакою (ст. 2). Пакт покладає на держави обов'язок передбачити в національному законодавстві заборону не тільки дискримінації будь-якого роду (ст. 26), але й будь-якого відступу «на користь національної, расової чи релігійної ненависті, що являє собою підбурювання до дискримінації, ворожнечі або насильства» (ст. 20). Крім того, ст. 4 Пакту передбачає, що під час надзвичайного становища в державі, при якому життя нації перебуває під загрозою і про наявність якого офіційно оголошується, держави-учасниці цього Пакту можуть вживати заходів на відступ від своїх зобов'язань за цим Пактом тільки в такій мірі, в якій це диктується гостротою становища, при умові, що такі заходи не є несумісними з їх іншими зобов'язаннями за міжнародним правом і не тягнуть за собою дискримінації виключно на основі раси, кольору шкіри, статі, мови, релігії чи соціального походження [13].

У Міжнародному пакті про економічні, соціальні та культурні права немає спеціальних положень про права національних меншин. Проте, відповідно до ст. 2 пакту держави, які беруть у ньому участь, зобов'язуються гарантувати, що проголошені в ньому права здійснюватимуться без будь-якої дискримінації, зокрема щодо раси, мови, релігії та національного походження. Держави-члени зобов'язуються гарантувати право кожної людини на працю та iї справедливі й сприятливі умови, право створювати професійні спілки, право на соціальне забезпечення, право на охорону сім'ї та дітей і достатнє харчування, одяг та житло, право на найвищий досяжний рівень фізичного і психічного здоров'я, право на освіту, право на участь у культурному житті [14]. Отже, держави які ратифікували Пакт визнають i гарантують перелічені права кожній людині без будь-якої дискримінації за вказаними ознаками, не зважаючи на належність особи до більшості чи меншості населення, її громадянство тощо.

Принцип недискримінації також закріплює Європейська конвенція про захист прав людини і основоположних свобод у ст. 14 , за якою користування правами та свободами, які визнані Конвенцією, має бути забезпечене без дискримінації за будь-якою ознакою [8]. Щоразу, коли 
Європейський Суд 3 прав людини розглядає питання про можливе порушення ст. 14 , він робить це у поєднанні з основним конвенційним правом. Заявники часто оскаржують порушення основного права і додатково - порушення цього права у поєднанні зі ст. 14. Іншими словами, втручання в їхні права, окрім порушення стандартів дотримання основного права, становить також дискримінацію. Протокол № 12 забороняє дискримінацію у «здійсненні будь-якого передбаченого законом права», а отже, має більш широку сферу застосування, ніж ст. 14 , яка поширюється тільки на права, зазначені в Європейської конвенції про захист прав людини і основоположних свобод. Слід зазначити, що протокол гарантує захист від дискримінації насамперед з боку держави, разом з тим він розповсюджується також і на відносини між приватними особами, які зазвичай підлягають державному регулюванню, «наприклад, на свавільну відмову у працевлаштуванні, відмову в доступі до ресторанів або послуг, що можуть надаватися громадськості приватними особами, наприклад медичних послуг або комунальних послуг, таких як постачання води чи електроенергії» [21].

У грудні 1965 року Генеральна Асамблея приймає Міжнародну конвенцію про ліквідацію всіх форм расової дискримінації, адже дискримінація за расовими ознаками була визнана найпоширенішим джерелом політичних та громадянських конфліктів. Расова дискримінація визначена як «будь-яке розрізнення, виняток, обмеження чи перевагу, основані на ознаках раси, кольору шкіри, родового, національного чи етнічного походження», що перешкоджає здійсненню прав людини i основних свобод. Відповідно до прийнятої Конвенції був вперше заснований орган, функції якого полягають у спостереженні за дотриманням всіх затверджених положень Комітет по ліквідації расової дискримінації, який складається 3 вісімнадцяти експертів, що відзначаються високими моральними якостями i визнаною безсторонністю, обираються Державами-учасницями з числа їх громадян і повинні виконувати свої обов'язки від себе особисто, причому приділяється увага справедливому географічному розподілу і представництву різних форм цивілізації, а також головних правових систем [12].

Рамкова Конвенція в історичному контексті стала першим, юридично обов'язковим, багатостороннім, міжнародним документом, присвяченим безпосередньо захисту національних меншин у всіх сферах суспільного життя. В правовому документі закладено принцип, згідно 3 яким усі іï положення запроваджуються виключно через національне законодавство кожної держави та її державну політику.

На національному рівні, Конституція України гарантує громадянам рівні конституційні права i свободи та рівність перед законом (ст. 24) без будь-яких привілеїв чи обмежень [9]. У вітчизняній правовій системі створена правова база, спрямована на боротьбу із правопорушеннями на грунті ненависті. Негативні наслідки правопорушень, вчинених на грунті ненависті, стосуються не лише окремо взятих осіб та груп, а посягають на весь суспільний порядок і становлять загрозу для 
кожного члена суспільства. Обов'язком української держави $\epsilon$ охорона та забезпечення безпеки людей, які перебувають на їі території, незалежно від раси, національності, етнічного походження, мови, кольору шкіри, релігії, віку, фізичних можливостей, сексуальної орієнтації, гендерної ідентичності або інших ознак.

У листопаді 2012 року набув чинності Закон України «Про засади запобігання та протидії дискримінації в Україні» від 6 вересня 2012 року № 5207-VI, який визначає організаційно-правові засади запобігання та протидії дискримінації з метою забезпечення рівних можливостей щодо реалізації прав і свобод людини і громадянина. Положення закону передбачають заборону проявів будь-якої дискримінації. Винятком може бути лише так звана «позитивна дискримінація» - дії, спрямовані на усунення юридичної чи фактичної нерівності у можливостях для особи та/або групи осіб реалізовувати рівні права і свободи [17].

Покарання за дискримінацію на расовому чи етнічному грунті передбачено у Кримінальному кодексі України, який містить низку статей в Загальній та Особливій частинах, які передбачають більш суворе покарання за злочини, скоєні з мотивів расової, національної або релігійної нетерпимості (що $€$ злочинами на грунті ненависті). Стаття 161 встановлює кримінальну відповідальність за умисні дії, спрямовані на розпалювання національної, расової та релігійної ворожнечі та ненависті, а також за дискримінацію за відкритим списком ознак [11]. Проте ця стаття також рідко застосовується на практиці, оскільки у суді важко дове- сти умисність дій. У 2009 році були внесено зміни до Кримінального кодексу України, які посилили кримінальну відповідальність за окремі злочини, вчинені на грунті нетерпимості [16 ].

Експерти Ради Європи критикують недосконалість українського законодавства щодо дискримінації. Зокрема, Кримінальний кодекс України не передбачає покарання за підбурювання до ненависті, мотивованої гомофобією, а в Законі України «Про засади запобігання та протидії дискримінації» не згадується про те, що сексуальна орієнтація може бути підставою для дискримінації. У Верховній Раді України зареєстровано Проект Закону № 3316 від 09.04.2020 р. «Про внесення змін до Кримінального кодексу України (щодо протидії злочинам на грунті ненависті за ознаками сексуальної орієнтації та гендерної ідентичності)» 20]. Він викликав хвилю протестів 3 боку громадськості, церкви i релігійних організацій різних конфесій.

Злочини на грунті ненависті $€$ злочинами, в основі яких лежать упередження. Такі злочини трапляються скрізь, адже жодне суспільство не застраховане від наслідків упередженості і нетерпимості. Злочини на грунті ненависті посилають сигнал неприйняття цілим громадам і несуть у собі зерно потенційних конфліктів, оскільки вони можуть зрости як кількісно, так і з огляду на рівень насильства. В Україні від злочинів на грунті ненависті найчастіше потерпають: іноземці, члени різних етнічних громад та релігійних меншин, ЛГБТ спільноти [5, с. 16-17]. Показником наявності упередження є факт або низка фактів, які дають підстави 
вважати, що злочин могло бути вчинено саме через упередження. Такі показники служать об'єктивними критеріями оцінки вірогідних мотивів злочину і можуть допомогти в попередньому виявленні випадків вчинення злочинів на грунті ненависті.

Загалом в українському судочинстві рідко застосовуються положення про злочини на грунті расової ненависті, і як наслідок кількість вироків за цими статтями дуже низька.

А. Кравчук у своєму дослідженні наводить статистику про те, що українські державні інституції реєструють відносно невелику кількість проявів ксенофобії. Так, уповноважений ВРУ 3 прав людини за 2017 рік отримав 37 звернень щодо дискримінації за ознаками раси, кольору шкіри та етнічного/національного походження. Додатково за результатами моніторингу 3MI, соціальних мереж та інших джерел інформації відкрито 16 проваджень за фактами ймовірних злочинів ненависті та 14 проваджень щодо мови ворожнечі за наведеними ознаками. Незалежні спостерігачі за 2017 рік надали ОБСЄ інформацію про 13 випадків дій на грунті расизму та ксенофобії, 4 - на грунті ромофобії та 21 - на грунті антисемітизму (з яких 20 полягали у пошкодженні майна). У 2016 році такі дані включали 7 випадків дій на грунті расизму та ксенофобії (зокрема, 5 нападів на людей) і 21 - на грунті антисемітизму (з яких 17 випадків пошкодження майна). Автор, робить висновок про те, що в офіційній статистиці та даних неурядових організацій випадки проявів ксенофобії та расизму часто згадуються разом, що не дає змоги відокремити злочини та інциденти ненависті за національною ознакою від расистських. Водночас прояви ксенофобії проти ромів та євреїв згадуються окремо від інших етнічних/національних груп [10, с. 43-44].

Наприкінці XX ст. проблема дискримінації ромів привернула увагу правозахисних організацій. Ромські активісти і захисники отримали підтримку від Інституту «Відкрите суспільство» (Нью-Йорк). У Раді Європи «ромська тема» стала одним зі спеціальних напрямків роботи: ведеться постійне спостереження за ситуацією з правами людини, проводяться семінари та тренінги для молодих ромів і юристів, що займаються захистом прав ромів, організовуються відкриті обговорення проблем ромського населення. За участю правозахисників різних країн, у 1995 році створено Європейський Центр з захисту прав ромів, діючий в Будапешті 3 представництвами в багатьох країнах як Західної, так і Східної Європи. Громадськість Європейських держав почала звертати увагу на випадки насильства проти ромів, що все частіше траплялися з боку поліції. На той час практика ЄСПЛ не враховувала расистських мотивів насилля. Погоджуючись 3 існуванням позитивних обов'язків держав щодо проведення ефективного розслідування фактів насильницького позбавлення життя, катування та нелюдського поводження, Суд не наважувався поширити такий самий підхід до випадків застосування насилля на расовому підгрунті.

Такий підхід змінюється 3 прийняттям рішення по справі «Начова та інші проти Болгарії». Справа 
стосувалася смерті двох молодих ромських чоловіків яких застрелили в одному з ромських поселень, де вони ховалися після втечі 3 місця відбування покарання у вигляді позбавлення волі за самовільне залишення військової служби. Посилаючись на велику кількість проявів дискримінації та ворожнечі щодо ромів у Болгарії, заявники - родичі загиблих говорили про порушення ст. 14 Конвенції у поєднанні зі ст. 2, вказуючи на те, що надмірне насильство до ромів було застосоване з боку представників влади саме через їхнє етнічне походження. Цінність цього рішення полягає в тому, що Суд встановив процедурні зобов'язання, згідно з якими держава має розслідувати дискримінаційні мотиви насильницьких злочинів, якщо $є$ обгрунтована підозра щодо таких мотивів.

Європейський суд з прав людини, у своїх рішеннях наголошує, що злочини на грунті нетерпимості вимагають від держави особливо рішучої відповіді - «держава повинна використовувати усі доступні їй засоби для боротьби з насильством на грунті нетерпимості, укріплюючи, таким чином, демократичні принципи толерантності та плюралізму» [15]. ЄСПЛ неодноразово наголошував на тому, що застосування однакових методів і підходів до розслідування злочинів на грунті нетерпимості та до інших насильницьких злочинів, які не мають такого мотиву, є невірним, оскільки це означає, що держава ігнорує особливо руйнівну для прав людини природу злочинів на грунті нетерпимості.

Першою українською справою про дискримінацію, в якій Європейський суд 3 прав людини визнав
Україну винною в недотриманні ст. 14 Європейської Конвенції з прав людини разом зі ст. 2 Європейської конвенції, яка регламентує право на життя і необхідність якнайшвидшого, ефективного та неупередженого розслідування $\epsilon$ справа «Федорченко і Лозенко проти України», рішення по якій ухвалено 20 вересня 2012 року. Текст рішення справи стосується нападу на сім'ю ромів 28 жовтня 2001 року, в результаті якого їхнє житло було спалено, а п'ятеро членів сім'ї, включаючи двох шестирічних дітей, загинули в результаті пожежі. Європейський суд 3 прав людини встановив порушення: державні органи обмежилися лише базовими процесуальними кроками. Крім того, ЄСПЛ зазначив, що ніхто 3 шістьох підозрюваних (крім Н.) так і не був знайдений.

Враховуючи поширені акти насильства i дискримінації щодо ромів в Україні, Європейський суд не виключив, що рішення про підпал будинків додатково підкріплювалося етнічною ненавистю. Проте відсутні будь-які докази того, що органи влади перевіряли версію про ксенофобні мотиви нападу. ЄСПЛ визнав неприйнятним, що у вказаних обставинах в ході розслідування, яке тривало більше 11 років, не було зроблено ніяких істотних дій, спрямованих на ідентифікацію і засудження винних. Україну зобов'язали виплатити заявниці 20 тисяч євро відшкодування моральної шкоди. Це перша справа, яку українські роми виграли в Європейському суді [23 ].

ЄСПЛ вказав на наявність у складі злочину расистських мотивів, що позначиться на майбутній судовій практиці. Адже в Україні зазвичай уникають такої кваліфікації 
справ, які стосуються національних меншин, що стали жертвами насилля. Також рішення Європейського суду 3 прав людини чітко підкреслюють, що наявність порушення прав людини та захищеної від дискримінації ознаки у жертви порушення, ще не означає наявність дискримінації.

Наступна справа про дискримінацію, це рішення ЄСПЛ у справі «Бурля та інші проти України», прийнято 6 листопада 2018 року. Події відбувалися у вересні 2002 року у селі Петрівка Одеської області. Суд дійшов висновку про те, що було порушено право на повагу до приватного життя і сімейного, житла і кореспонденції (стаття 8 Європейської конвенції з прав людини) та заборону дискримінації (ст. 14), а також заборону катувань та поводження, що принижує людську гідність (ст. 3). За рішенням ЄСПЛ заподіяна будинкам заявників шкода становила серйозне та необгрунтоване втручання у право заявників на повагу до їхнього приватного та сімейного життя і житла. Європейський суд з прав людини зобов'язав Україну виплатити 5 мільйонів гривень компенсації постраждалим внаслідок погрому ромського табору на Одещині [2].

3 метою створення належних умов для захисту та інтеграції в українське суспільство ромської національної меншини, забезпечення рівних можливостей для їі участі у соціально-економічному та культурному житті держави Указом Президента України від 08.04.2013 р. № 201 схвалено Стратегію захисту та інтеграції в українське суспільство ромської національної меншини на період до 2020 року. Основні завдання Стратегії полягають у сприянні правовому, соціа- льному захисту ромів, сприянні їх зайнятості, підвищення освітнього рівня, забезпеченні охорони здоров'я ромів, поліпшенні житлово-побутових умов ромів, задоволенні культурних та інформаційних потреб ромів [19]. У 2013 році Кабінет Міністрів затвердив план заходів щодо реалізації стратегії захисту та інтеграції в українське суспільство ромської національної меншини на період до 2020 року, яким визначені конкретні заходи спрямовані на інтеграцію в українське суспільство ромської національної меншини та їх виконавці [18].

Сучасна державна політика України, з одного боку, спрямована на включення ромів до соціальноекономічного життя країни, з іншого боку, далеко не завжди справляється із викликами ромофобії, які склалися у суспільстві, з проявами дискримінації ромської національної меншини. Про те, що законодавство та правозастосовча практика в Україні щодо боротьби із нетерпимістю та злочинами на грунті ненависті, досі залишаються недосконалими та неефективними, свідчить і Доповідь Європейської комісії проти расизму та нетерпимості (ЄКРН) п'ятого циклу моніторингу щодо України від 20 червня 2017 року. ЄКРН - це особливий, незалежний та контрольний орган 3 моніторингу прав людини, який спеціалізується на питаннях, пов'язаних 3 боротьбою проти расизму, дискримінації (за ознакою «раси», етнічного/ національного походження, кольору шкіри, громадянства, віросповідання, мови, сексуальної орієнтації та гендерної ідентичності), ксенофобії, антисемітизму та нетерпимості у Європі; він готує звіти та видає рекомендації держа- 
вам-членам. Комісія складається 3 незалежних та неупереджених членів, яких призначають 3 огляду на їхній моральний авторитет та визнаний досвід у розгляді питань, пов'язаних із расизмом, ксенофобією, антисемітизмом та нетерпимістю. У межах своєї статутної діяльності ЄКРН проводить покраїнну моніторингову роботу, яка включає аналіз ситуації в кожній із держав-членів Ради Європи щодо расизму та нетерпимості й робить пропозиції та рекомендації про способи розв'язання виявлених проблем.

2 червня 2020 року ЄКРН опублікувала висновки щодо виконання двох пріоритетних рекомендацій, наданих Україні у 2017 році. Поперше, ЄКРН наполегливо рекомендувала включити питання сексуальної орієнтації та гендерної приналежності до Кримінального кодексу у якості підстави та вважати їх обтяжуючими обставинами. У зв'язку з цим ЄКРН зазначає, що згідно 3 Кримінальним кодексом, покарання за розпалювання ненависті чи насильства, мотивованого гомо/трансфобією не відбувається. Крім того, в обставинах, що обтяжують покарання, немає посилань на підстави сексуальної орієнтації та гендерної приналежності під обтяжуючими формами певних злочинів або у статті Кримінального кодексу. ЄКРН зазначає лише одну правку до Кримінального кодексу, яка набула чинності у 2019 році - включення підстав «сексуальної приналежності». Хоча, включення гендерного питання до числа обставин, що обтяжують покарання, вітається, але воно не поширюється на сексуальну орієнтацію чи гендерну приналежність, а тому не відповідає реко- мендації, зазначає ЄКРН. Це означає, що її рекомендація не була виконана.

По-друге, ЄКРН рекомендувала відмовитись від судових зборів у справах ромів, які прагнуть довести свою особу з метою отримання особистих ідентифікаційних документів. Влада повідомила ЄКРН, що Закон про судові збори 2012 року передбачає відстрочку сплати судового збору, зменшення його суми або звільнення від сплати. ECRI, однак, розуміє, що законодавство $є$ малосприятливим для ромів, які прагнуть довести свою особу, оскільки - як це не парадоксально - існує вимога довести нездатність сплачувати збори шляхом надання документальних доказів суду. У цьому контексті ЄКРН не виявила жодних ознак застосування цього положення в таких випадках [24]. Отже, звідси висновок - рекомендація не була виконана, оскільки, вся зібрана інформація свідчить про те, що в цьому відношенні не відбулося жодних змін.

Висновки. На підставі вищевикладеного можна зробити висновок, що дискримінація за расовою або етнічною ознакою - особливо образливий вид дискримінації. Дискримінація меншин залишається центральною проблемою і впливає на реалізацію всіх прав. Міжнародне право прав людини забороняє дискримінацію за ознакою раси, кольору шкіри, мови, національного чи соціального походження, або іншого статусу. Ці стандарти в галузі прав людини вимагають від державучасниць вжити всіх належних заходів для ліквідації дискримінації і забезпечення виконання даного обов'язку всіма державними органами та установами. Злочини ненависті 
$€$ результат жорстокості, i, зостаючись без належного правового реагування, поширюються на великі спільноти. Впровадження в Україні антидискримінаційного права $€$ передумовою іiі становлення як європейської правової держави. Будь-яка потерпіла особа має право звернутися за захистом свої прав до омбудсмена та/або суду. При цьому, за подання позовів щодо спорів, пов'язаних із дискримінацією, судовий збір не сплачується. Підтримка та реалізація антидискримінаційної політики має бути забезпечена на всіх рівнях державної влади.

Впровадження у національну правову систему механізмів та інструментів, які спроможні зупинити чи зменшити ненависть та захистити людську гідність, автономію та рівність кожної людини, створює основу ефективного захисту фундаментальних цінностей, людяності та гуманізму.

\section{Список використаних джерел}

1. Ангелова та Ілієв проти Болгарії (Angelova and Iliev v. Bulgaria) від 26.07.2007 № 55523/00 URL: https://zakon.rada.gov.ua/laws/show/980_171\#Техt (дата звернення: 11.08.2020).

2. Бурля та інші проти України від 06. 11. 2018 (остаточне 06.02.2019) № 3289/10 URL: https://zakon.rada.gov.ua/laws/show/974_d65\#Text (дата звернення: 10.09.2020).

3. Вовк Д., Бойчук С. Верховенство права і толерантність: навчальний посібник. Київ, 2018. 172 с.

4. Галан В.О. Дискримінація за расовою ознакою: від апології рабства до міжнародно-правового злочину. Форум права. 2014. № 3. С.52-62.

5. Доповідь Європейської комісії проти расизму та нетерпимості (ЄКРН) щодо України (п'ятий цикл моніторингу), ухвалено 20 червня 2017 р., опубліковано 19 вересня 2017 p. URL: https://rm.coe.int/fifth-report-on-ukraine-ukrainiantranslation/16808b5саа (дата звернення: 10.09.2020).

6. Журавльова Г. С. Конституційні аспекти заборони дискримінації в Україні й іноземний досвід. Науковий вісник публічного та приватного права. Вип.6, том 1. 2016. С. 40-44.

7. Загальна декларація прав людини від 10 грудня 1948 p. URL: http://zakon4.rada.gov.ua/laws/show/995_015 (дата звернення: 10.09.2020).

8. Конвенція про захист прав людини і основоположних свобод від 11 листопада 1950 p. URL: http://zakon2.rada.gov.ua/laws/show/995_004 (дата звернення: 01.09.2020).

9. Конституція України: Прийнята на V сесії Верховної Ради України 28 червня 1996 р. Відомості Верховної Ради України. 1996. № 30. Ст. 141. URL: http://zakon2.rada.gov.ua/laws/show/254\%D0\%BA/96-\%D0\%B2\%D1\%80 (дата звернення: 10.09 .2020$)$.

10. Кравчук А. Злочини та інциденти ненависті в Україні. К: Центр «Наш світ», 2018. 95 c.

11. Кримінальний кодекс України від 5. 04. 2001 року № 2341-III. URL: https://zakon.rada.gov.ua/laws/show/2341-14\#Text (дата звернення: 10.09.2020).

12. Міжнародна конвенція про ліквідацію всіх форм расової дискримінації. URL: https://zakon.rada.gov.ua/laws/show/995_105\#Text (дата звернення: 10.09.2020).

13. Міжнародний пакт про громадянські і політичні права. URL: https://zakon.rada.gov.ua/laws/show/995_043 (дата звернення: 10.09.2020). 
14. Міжнародний пакт про економічні, соціальні і культурні права: URL: https://zakon.rada.gov.ua/laws/show/995_042\#Text (дата звернення: 10.09.2020).

15. Начова та інші проти Болгарії (Nachova and Others v. Bulgaria): рішення ЄСПЛ №№ 43577/98, 43579/98 від 06.07.2005 p. URL: https://www.srji.org/ resources/search/21/(дата звернення: 10.09.2020).

16. Про внесення змін до Кримінального кодексу України щодо відповідальності за злочини з мотивів расової, національної чи релігійної нетерпимості: Закон України від 05.11. 2009 p. URL: https://zakon.rada.gov.ua/laws/show/1707-17\#Tехt (дата звернення: 10.09 .2020$)$.

17. Про засади запобігання та протидії дискримінації в Україні: Закон України від 6 вересня 2012 року № 5207-VI URL: https://zakon.rada.gov.ua/laws/show/520717\#Text (дата звернення: 10.09.2020).

18. Про затвердження плану заходів щодо реалізації Стратегії захисту та інтеграції в українське суспільство ромської національної меншини на період до 2020 року: розпорядження Кабінету Міністрів України від 11. 092013 р. № 701-p. URL: https://zakon.rada.gov.ua/laws/show/701-2013-\%D1\%80\#Text (дата звернення: 04.09.2020).

19. Про Стратегію захисту та інтеграції в українське суспільство ромської національної меншини на період до 2020 року: Указ Президента України від 08.04. 2013. № 201/2013. URL: https://zakon.rada.gov.ua/laws/show/201/2013\#n10(дата звернення: 10.09.2020).

20. Проект Закону про внесення змін до Кримінального кодексу України (щодо протидії злочинам на грунті ненависті за ознаками сексуальної орієнтації та гендерної ідентичності) від 09.04.2020 № 3316 URL: http://w1.c1.rada.gov.ua/ pls/zweb2/webproc4_1?pf3511=68552 (дата звернення: 10.09.2020).

21. Протокол № 12 до Конвенції про захист прав людини і основоположних свобод (ETS № 177) URL: https://zakon.rada.gov.ua/laws/show/994_537\#Tехt(дата звернення: 10.09.2020).

22. Радчук О. П. Європейська Конвенція про захист прав найбільш вразливих верств населення. Теорія і практика правознавства. Вип. 1 (5). 2014. С. 1-14.

23. Федорченко та Лозенко проти України: рішення ЄСПЛ № 387/03 від 20.09.2012 p. URL: https://zakon.rada.gov.ua/laws/show/974_933\#Text (дата звернення: 10.09.2020).

24. News of the European Commission against Racism and Intolerance (ECRI). Denmark, Montenegro, Serbia, Ukraine: Council of Europe's anti-racism commission publishes conclusions on implementation of its priority recommendations. Strasbourg, France. 2 june 2020. URL: https://www.coe.int/en/web/european-commission-against-racism-andintolerance/-/denmark-montenegro-serbia-ukraine-council-of-europe-s-anti-racismcommission-publishes-conclusions-on-implementation-of-its-priority-recommendations (дата звернення: 10.09.2020).

\section{References}

Boychuk, S., Vovk D. (2018). Rule of law and tolerance. Kyiv [in Ukrainian].

Galan, V.O. (2014). Discrimination on racial grounds: from the apology of slavery to international crime. Law Forum, 3, 52-62 [in Ukrainian].

Zhuravlyova, G.S. (2016). Constitutional aspects of non-discrimination in Ukraine and foreign experience. Scientific Bulletin of Public and Private Law, 6, 1, 40-44 [in Ukrainian].

Kravchuk, A. (2018). Hate crimes and incidents in Ukraine. Kiev: Our World Center [in Ukrainian].

Radchuk, O. P. (2014). European Convention for the Protection of the Rights of the Most Vulnerable. Theory and practice of jurisprudence, 5, 1-14 [in Ukrainian]. 
L. Matvieieva, Doctor of Law, Associate Professor, Department of Theory and Philosophy of Law, Odessa State University of Internal Affairs

ORCID: 0000-0002-8402-5584

\section{International and European protection standards of the rights of vulnerable groups of population}

The article presents scientific categories: discrimination, hate crimes, vulnerable groups. It is studied the issues of legal protection of vulnerable categories of population in the context of formation of active human rights policy of state aimed at increasing the capacity of socially vulnerable groups and reducing the risks of growing social tensions in society. The analysis' results of the European experience in combating intolerance and discrimination and development of proposals for improving domestic legislation are presented.

The urgency of the problem is exacerbated by the fact that discrimination, as a manifestation of violations of the rights of members of certain groups (on the basis of age, health, social status, nationality, etc.) causes global negative consequences for society and state. Violation of the rule of law, legality, leveling of the rule of law, negative impact on international image of the state - only a small list of political and legal consequences of discrimination.

In the current crisis, the population of Ukraine is acutely aware of instability in families, personal security, in social environment, as well as in global politics. The general situation with respect for human rights in the state is reflected in numerous violations of the rights of vulnerable groups, which should cause special attention and concern to public authorities and human rights organizations

In the study of the EU and Ukraine legal systems' essence in their relationship, a civilizational approach becomes relevant, which allows to establish legal elements through the prism of the diversity of scientific positions of representatives of different legal systems and legal cultures. It helps to identify the national legal system' features in the field of functioning of law principles and norms, pointing to the uniqueness of legal system of Ukraine and at the same time emphasizing the shortcomings and differences caused by public awareness, law enforcement.

The normative basis of legal protection study of vulnerable groups is the acts of current legislation of Ukraine, international acts in the field of protection of human rights and freedoms, as well as the case law of the European Court of Human Rights.

Keywords: discrimination; hate crimes; human rights; ECHR practice; vulnerable groups. 